\title{
Implementation of Private Teacher Protection Policies
}

\author{
Fahriza Marta Tanjung \\ Educational Administration \\ Department \\ Post Graduate Program Universitas \\ Negeri Medan \\ Medan, Indonesia \\ Coresponding email : \\ fahriza.marta@gmail.com
}

\author{
Darwin \\ The Lecturer of Universitas Negeri \\ Medan \\ Medan, Indonesia
}

\author{
Restu \\ The Lecturer of Universitas Negeri \\ Medan \\ Medan, Indonesia
}

\begin{abstract}
This study aims to determine the application of the private teacher protection policy in Medan based models Mazmanian and Sabatier. The object of this study is Permendikbud Number 10 of 2017 on the Protection of Teachers and Education Personnel. The data collection was done by interview, observation, and documentation. Data were analyzed using presentation, reduction and conclusions. The results showed that the first, the teacher protection policy has been unable to protect private teachers. Second, external factors that affect the implementation of the protection policies of private teachers are not yet available. Third, the process of implementing private teacher protection policies has not yet been carried out. The implementation of a policy of protection for private teachers has not yet been implemented due to the lack of socialization of policies and the absence of implementation instructions from authorized officials. This study concludes that the implementation of private teacher protection policies has not been implemented following Permendikbud Number 10 of 2017.
\end{abstract}

Keywords-Policy Implementation; Private Teacher Protection

\section{INTRODUCTION}

The presence of Law No. 14 of 2005 concerning Teachers and Lecturers has given recognition to teachers as a profession. In the explanation of this Act, it is stated that to maximize the function and strategic role of teachers, it is necessary to uphold the rights and obligations of teachers as professionals, fostering and developing the teaching profession, legal protection, professional protection, and protection of occupational safety and health.

Related to efforts to protect teachers, in article 39 this law has regulated forms of teacher protection. Furthermore, the government through the Ministry of Education and Culture issued Permendikbud No. 10 of 2017 concerning Protection for Educators and Education Personnel. In this Permendikbud stated that in carrying out their duties teachers get protection in the form of a) Legal protection including legal protection against acts of violence, threats, discriminatory treatment, intimidation or unfair treatment on the part of students, parents of students, the public, bureaucracy or other party; b) Professional protection includes protection against termination of employment that is not in accordance with statutory regulations, the provision of improper rewards, restrictions on expressing views, harassment of the profession and other that can hinder teachers in carrying out their duties; c) Protection of occupational safety and health includes protection against the risk of disruption of work security, work accidents, fire during working hours, natural disasters, occupational health or other risks; and d) Protection in carrying out intellectual property rights including protection of copyright and industrial property rights.

Explicitly, the contents of this regulation have not been able to explain and translate the rules related to teacher protection. On the operational side, a very general interpretation of the teacher protection article makes the implementation of teacher protection not going well. Synergy with other laws outside the Teacher and Lecturer Law is also not carried out. As a result, efforts to protect teachers are not running optimally.

One case that was of great concern and concern was the death of a SMA Negeri Torjun teacher in Sampang as a result of being beaten by his students. The teacher Ahmad Budi Cahyono was beaten by his students for reprimanding students who did not pay attention to the lessons they were given. Another case was experienced by Mr. Dasrul, a SMK teacher in Makassar, who was beaten by students' parents. This beating resulted in Mr. Dasrul being hospitalized.

Not only dealing with parents, but several cases require teachers to deal with law enforcement. Mr. Muhammad Samhudi who is a teacher at SMP Raden Rachmat Sidoarjo received a sentence of imprisonment for 3 months and a fine of Rp 250.000,- with a trial period of 6 months for pinching his students who did not attend the Duha prayer. The same problem also befell Mrs. Nurmayani in Bantaeng, Mr. Mubazir in Sinjai Selatan, Mr. Arsal in Selayar District and Ibu Darmawati in Pare-Pare who have to deal with the law because it is polished by students' parents.

Another case was also faced by Mr. Ruslianto et al who was transferred as structural employees because they were suspected of being the driving force of the demonstration against the Principal. Even though they have won their lawsuit at PTUN, they have not been returned as teachers. If PNS teachers are vulnerable to being transferred, private teachers are vulnerable to being fired as experienced by Ms. Sunarni. He was dismissed because he refused the foundation's request which was not by following the rules of building library space assistance they received. 
Not only vulnerable to being fired, for private teachers, but there are also still many who have not received salaries by the provisions of the Act that should be equivalent to the UMR. The low income of these honorary teachers forced them to have additional work to earn additional income. Starting from motorcycle taxi drivers, trading, sales, farming, raising livestock and teaching in several schools. Ironically, these honorary teachers with small salaries are also paid late even once every few months.

The cases above show how weak protection of teachers is, especially for private or non-PNS teachers. Even though the role of the private teacher cannot be underestimated. Data on the number of teachers in Medan in the following table shows how important the role of private teachers is. There are 25,801 teachers in Medan, around $67 \%$ of them are private or nonPNS teachers with various statuses.

Starting from the phenomenon of cases that have occurred, it appears that efforts to protect teachers, especially for private teachers, have not been going well. Further data mining is needed to see whether the initial data is indeed true. The Teachers and Lecturers Law and the Minister of Education's Teachers and Education Personnel Protection Regulation, are policies that ultimately aim to improve the quality of education. Even if this policy is not implemented properly then there are problems in its implementation. As mentioned Tilaar and Nugroho that in the success of a policy $20 \%$ is determined by the policy plan, $60 \%$ by the implementation of the policy and the remaining $20 \%$ is how the implementation of the policy is controlled [1].

Hill and Hupe mention that there are several models that can be used to study the implementation of a policy [2]. The Merilee S Grindle model states that the process of policy implementation is a political and administrative activity that is influenced by the content of the policy and the context of policy. Furthermore, Van Meter and Van Horn mentioned that there are 6 things that will affect policy performance, namely: a) policy standards and objectives; b) available resources and incentives; c) the quality of relationships between organizations; d) characteristics of implementing agents; e) economic, social and political environment; and f) the disposition or response of the implementation. While George C. Edwards III stated that there were four crucial factors in policy implementation, namely communication, sources, tendencies or behavior, and bureaucratic structure.

This research itself will use the Sabatier and Mazmanian model outlining the variables that affect a policy implementation process are (a) tractability of the problem; (b) the ability of statute to structure implementation; and (c) nonstatutory variables affecting implementation [3]. This model was chosen because according to Purwanto and Sulistyati the Sabatier and Mazmanian models are the most complete models in gathering a number of factors from various models that use the top-down approach to become a more comprehensive model [4].

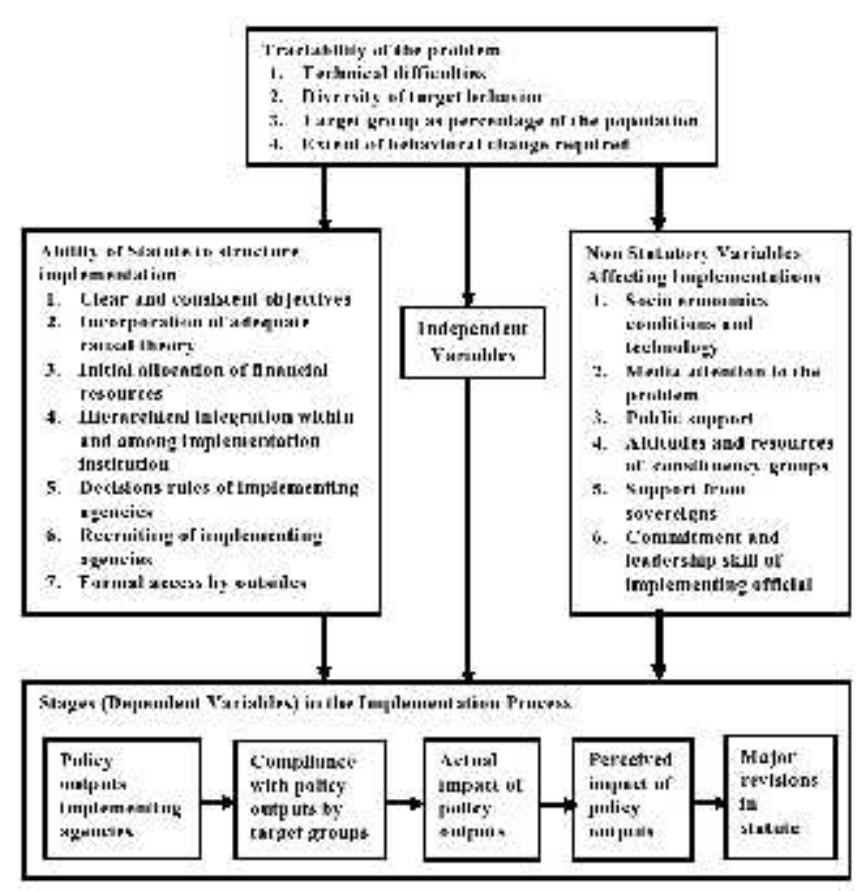

Fig 1. Sabatier and Mazmanian Policy Implementation Models (1980 : 542)

As seen in the figure, each variable has several factors as independent variables which then influence the implementation process as the dependent variable. This research itself does not use the level of difficulty of the problem that must be resolved as a variable that influences policy implementation. This variable requires the researcher to conduct a study of the policy formulation process, which will make it difficult for researchers to explore the problem. Furthermore, this component requires the existence of an academic text of the policy so that an overview of the problems to be resolved from the policies issued can be obtained. Based on this choice, the objective of the research is to find the ability of regulations to support policy implementation, find external factors that influence policy implementation and find the process of implementing protection policies for private teachers in Medan.

Similar research ever conducted by Nisa et al against teachers in Semarang on a different focus [5]. This study found that teachers would feel safe and comfortable if Permendikbud No. 10 of 2017 could be realized. But the teachers considered that until now the role of the Permen is still not maximal.

\section{Methodology}

This research uses a qualitative approach with a case study method. In connection with the object of research, namely Permendikbud No. 10 of 2017, this study is included in the category of policy research focused on policy implementation. The subjects of his research were the Chairperson of the Foundation and the Principal of the SMP Brigjen Katamso II Medan as the main informant, the Head of the Medan City Education Office, the Chairperson of the Republic of Indonesia Teachers Association (PGRI) of Medan City and the teacher of SMP Brigjen Katamso II Medan. This study also 
uses snowball sampling techniques in the selection of research subjects.

Research data collection using interview techniques where researchers will conduct interviews directly using semistructured interviews with interview guides. Research data is also collected through observation techniques, namely passive observation where the researcher is not involved at all in the social situation under study. Observation and interview techniques are supplemented by documentation, where the documents collected are related to the implementation of the private teacher protection policy.

The Miles and Huberman technique is used as a technique for analyzing data that is carried out interactively and continues continuously until it is complete or the data is saturated. Activities undertaken in data analysis are data reduction, data display and conclusion drawing/ verification.

Testing the validity of the data using a credibility test with triangulation techniques. Triangulation includes using reference materials, member checking and increasing perseverance.

\section{RESULTS AND DISCUSSION}

In general, the findings obtained are that teacher protection policies are still running partially and do not refer to the provisions in Permendikbud No. 10 of 2017. Not all forms of teacher protection are given by related parties, out of 4 forms of teacher protection, namely legal protection, protection profession, protection of occupational safety and health as well as protection of intellectual property rights, only the protection of the profession which has a tendency to be implemented well. The implementation of professional protection for teachers is not directly related to the implementation of Permendikbud No. 10 of 2017 but is related to the function of schools in serving their students to get the guidance, education, and teaching through intracurricular, cocurricular and extracurricular activities.

This condition is caused by the absence of Permendikbud No. 10 of 2017 socialization from the Government, through the Ministry of Education and Culture, to the Regional Government, both the Provincial Education Office and the District/ City Education Office. As a result, information related to the Permendikbud does not reach the education unit, both the foundation as the school owner and the School Principal as the school manager. In accordance with the provisions of the Permendikbud, there are several institutions that have the obligation to provide protection to teachers, namely the government, regional governments, education units, professional teacher organizations, and the community. Only teacher professional organizations, researchers took data from the Medan City of PGRI Board, which has an orientation to implementing teacher protection policies even though they are not directly related to the implementation of Permendikbud No. 10 of 2017 but more because they carry out their duties and functions as professional organizations which they have run long before Permendikbud there is.

In another part, it was also found that Permendikbud No. 10 of 2017 does not yet have clear directions on what and how to be done by related agencies that have an obligation to carry out this Permendikbud. Permendikbud only mentions that the said institution has an obligation to provide teacher protection by providing resources and setting up a mechanism for providing protection. Further provisions on these obligations are not explained in this Permendikbud and even technical guidelines, which are the obligations of the Director-General in relation to making them, have not yet existed until now. More detailed findings from this study will be presented in the following description.

\section{A. The Ability of Statute to Structure Implementation}

The study found that regulations do not yet have a clear and consistent purpose. The purpose of the regulation has not been carefully arranged and does not have a sequence of interests which parts should be prioritized.

As a result of the lack of socialization of regulations and implementation instructions, the regulations made have not been able to support policy implementation. One of them is the absence of a hierarchical cohesiveness between implementing agencies in the implementation of teacher protection policies. Only Medan City of PGRI has the readiness to implement this teacher protection policy.

The next follow-up effect was the lack of recruitment of implementing officials, particularly at the school level or the Education Office. While the Medan City of PGRI already has implementing officials to implement teacher protection in accordance with the provisions in PGRI's Statutes/ By-Laws and is not directly related to the presence of Permendikbud No. 10 of 2017.

This condition has resulted in the absence of a special budget to support teacher protection policies. Even if available and in line with the teacher protection policy is more dominant related to the smooth teaching and learning process in the classroom not related to teacher protection policies. The unavailability of the budget makes it difficult to conduct an assessment and measurement of the accuracy of the allocation of funding sources, both in terms of supply, amount and amount and use.

Like the domino effect, the next finding is that implementing institutions for teacher protection policies, both the Medan City Education Office and SMP Brigjen Katamso II Medan, do not yet have rules for implementing these policies. Only the Medan City of PGRI already has implementing regulations for the teacher protection policy, although indeed, the implementing regulations owned by the Medan City of PGRI are not directly related to the existence of Permendikbud No. 10 of 2017.

Another finding is that formal access to outsiders already exists and has been established. Formal outside access is established in order to protect teachers from possible violence from other parties and their impacts. But this access is only incidental, if needed, without an agreement on cooperation.

\section{B. Non-Statutory Variables Affecting Implementation}

One external factor that influences the implementation of teacher protection policies is socio-economic conditions and technological mastery. Medan City as a big city in North Sumatra where SMP Brigjen Katamso II Medan is located can 
be classified as having good socio-economic conditions and technological mastery and can be concluded capable of supporting the implementation of teacher protection policies if this policy is implemented.

Next, it was found that media attention to the issue of teacher protection policies was not yet there. The presence of the is not only not supportive, but it could be that on one occasion the school, management of professional organizations and the education department faced journalists. Of course, this condition is not something that is expected in the implementation of teacher protection policies.

Likewise, support from the community has not been as expected. In general, the community, especially parents of students, will not pay more attention to the school as long as their children are well served by the school. On the other hand, sometimes the teacher has to deal with the community and students' parents if the teacher takes the disciplining action of the student, which is considered excessive by the parents while the teacher is normal.

Not much different, support from the authorities to implement the implementation of teacher protection policies, especially related to Permendikbud No. 10 of 2017, has not been done. Even though the authorities or the government, in this case, the Ministry of Education and Culture, the Mayor of Medan and the Medan City Education Office have carried out programs oriented to teacher protection but are not directly related to the existence of Permendikbud No. 10 of 2017.

Commitment and leadership skills of implementing officials, especially in the Medan City Education Office and SMP Brigjen Katamso II Medan, cannot be measured yet because the recruitment of implementing officials specifically to carry out policy implementation has not been carried out. While for the Medan City PGRI, it already has an official implementing the teacher protection policy as well as adequate commitment, competence and leadership because it is chosen selectively with various criteria.

\section{Policy Implementation Process}

The implementation of teacher protection policies, specifically the implementation of Permendikbud No. 10 of 2017, is an important part of this research. Policy output in the forms of teacher protection is one of the factors in this section. The study found that SMP Brigjen Katamso II Medan teachers had never experienced acts of violence and were never carried out unfairly and discriminatively. Schools do not yet have SOPs to deal with violence that may be experienced by teachers, but schools have made efforts to prevent violence from happening at school. Schools prioritize family planning meetings if there are teachers who experience violence.

Another form of protection is profession protection that has been carried out by SMP Brigjen Katamso II Medan against teachers. The efforts taken include the distribution of teaching assignments in accordance with competencies, interests, and talents, teachers have also been bound by work agreements and the rewards are also in the fair category. The protection of the teaching profession is also implemented by granting authority to teachers to provide grades and determine student graduation without any intervention. Teachers are also given academic freedom to express their views and the freedom to join professional organizations.

Furthermore, efforts to protect occupational safety and health have not received serious attention and have not been implemented in schools. Schools do not yet have rules or guidelines related to working safely in schools and do not yet have procedures in handling disasters that may occur. The foundation's efforts to disseminate disaster have not yet been felt by teachers at SMP Brigjen Katamso II Medan. While health insurance is still borne by the teacher personally. Efforts to protect intellectual property rights have not been implemented because there is no teacher's work that is worthy to be registered and the school has a commitment to help teachers get copyright protection if there are decent works.

The target group's compliance, in this case, SMP Brigjen Katamso II Medan teachers, on the output of teacher protection policies is still very low. Let alone to obey, they are not too concerned about the existence of teacher protection policies. Teachers are very obedient to the outputs of policies issued by foundations and principals because they are directly related to teaching and learning activities in class.

In another part, the legal protection efforts given to teachers have had an impact on teachers feeling safe to be in school and in the classroom. Law protection efforts for teachers are indeed not carried out systematically but the antiviolence culture that is instilled in school members is a guarantee that teachers will not experience acts of violence. the protection of the teacher makes the teacher better at teaching and the learning objectives easier to achieve.

Regarding the need to revise Permendikbud Number 10 of 2017 different opinions emerged. But there is a similar dissatisfaction with the inability of this Permen to provide protection to teachers. The difference starts from the moderate one by simply completing the implementation instructions up to the radical one who removes the Permen and replaces it with a law so that it has more legal force.

\section{CONCLUSIONS}

Based on the research findings and discussion, it can be concluded that:

1. Permendikbud No. 10 of 2017 does not have the ability to support teacher protection policies in Medan.

2. External factors that are able to influence the implementation of teacher protection policies in Medan have not been maximally fulfilled

3. The process of implementing teacher protection policies in Medan has not been fully implemented.

\section{ACKNOWLEDGMENT}

This research is a prerequisite for completing postgraduate study at Universitas Negeri Medan, therefore the researcher would like to thank the director and staff of the Postgraduate of Universitas Negeri Medan. The researcher also expressed his gratitude to the research subjects, namely the principal and teachers of the SMP Brigjen Katamso II Medan, Head of the Medan City Education Office, the PGRI Management of Medan City and the Management of the Brigjen Katamso National College Foundation. 


\section{REFERENCES}

[1]. H.A.R Tilaar, and Riant Nugroho, "Kebijakan Pendidikan : Pengantar untuk Memahami Kebijakan Pendidikan dan Kebijakan Pendidikan sebagai Kebijakan Publik," Yogyakarta : Pustaka Pelajar, 2009.

[2]. Michael Hill, and Hupe, "Implementing Public Policy," London : SAGE Publications, 2002.

[3]. Paul Sabatier, and Daniel Mazmanian, "The Implementation of Public Policy : A Framework of Analisys," in Policy Studies Journal, vol. $8,4^{\text {th }}$ ed, ISSN : 0190-292X, 1980, pp. 538-560.

[4]. Erwan Agus Purwanto, and Dyah Ratih Sulistyastuti, "Implementasi Kebijakan Publik, Konsep dan Aplikasinya di Indonesia," Yogyakarta : Penerbit Gava Media, 2012.

[5]. Aisyah Nur Sayidatun Nisa, Fredy Hermanto, Asep Ginanjar, an Noviani Achmad Putri, "Persepsi Guru Mengenai Permendikbud Nomor 10 Tahun 2017 tentang Perlindungan Pendidik dan Tenaga Kependidikan di Kota Semarang," in Harmony : Jurnal Pembelajaran IPS dan PKn, vol. 3, $2^{\text {nd }}$ ed, 2019, pp. 104-114. 